\title{
HIGHLIGHTS
}

\section{HIGHLIGHTS ADVISORS}

\section{UELI AEB}

UNIVERSITY OF BASEL, SWITZERLAND

TOM L. BLUNDELL

UNIVERSITY OF CAMBRIDGE, UK

JOAN S. BRUGGE

HARVARD MEDICAL SCHOOL, BOSTON, MA, USA

\section{PASCALE COSSART}

INSTITUT PASTEUR, PARIS, FRANCE

\section{PAMELA GANNON}

CELL AND MOLECULAR

BIOLOGY ONLINE

\section{SUSAN M. GASSER}

UNIVERSITY OF GENEVA, SWITZERLAND

\section{JEAN GRUENBERG}

UNIVERSITY OF GENEVA, SWITZERLAND

\section{ULRICH HARTL}

MAX-PLANCK-INSTITUTE, MARTINSRIED, GERMANY

\section{STEPHEN P. JACKSON}

WELLCOME/CRC INSTITUTE, CAMBRIDGE, UK

\section{WALTER NEUPERT}

MUNICH UNIVERSITY, GERMANY

\section{TONY PAWSON}

SAMUEL LUNENFELD RESEARCH INSTITUTE, TORONTO, CANADA

\section{NORBERT PERRIMON}

HARVARD MEDICAL SCHOOL, BOSTON, MA, USA

\section{THOMAS D. POLLARD}

YALE UNIVERSITY, NEW HAVEN, CT, USA

\section{JOHN C. REED}

THE BURNHAM INSTITUTE, LA JOLLA, CA, USA

\section{ANNE RIDLEY}

LUDWIG INSTITUTE FOR CANCER RESEARCH, LONDON, UK

\section{KAREN VOUSDEN}

BEATSON INSTITUTE FOR CANCER RESEARCH, GLASGOW, UK

\section{APOPTOSIS}

\section{I will survive}

A wide range of angiogenic factors not only contribute to the proliferation and invasiveness of endothelial cells (ECs), but also protect ECs from apoptosis. c-Raf (also known as Raf1), which is already known to be important for EC survival, is now implicated as a pivotal regulator of apoptosis. In Science, David Cheresh's group reports that differential regulation of Raf by basic fibroblast growth factor (bFGF) and vascular endothelial growth factor (VEGF) protects ECs from intrinsic- and extrinsicmediated apoptosis, respectively.

The group began by exposing ECs to either bFGF or VEGF while inducing apoptosis through stress (the intrinsic pathway) or receptormediated mechanisms (extrinsically). bFGF provided more effective protection against the former, whereas VEGF prevented the latter. These results were confirmed in vivo for both growth factors. Both bFGF and VEGF activate c-Raf, so to find out more about the role of Raf in this process, Cheresh's group used phosphospecific antibodies against two different sites in Raf: the Raf activation domain is phosphorylated (and activated) by p21-activated kinase (PAK) on serines 338 and 339 , or by Src on tyrosines 340 and 341. bFGF induced phosphorylation at the PAK site, whereas VEGF more effectively phosphorylated the Src site. Conversely, selectively blocking PAK or Src activity inhibited bFGFor VEGF-induced c-Raf activity, respectively.
Growth-factor-mediated activation of c-Raf activates extracellular signal-regulated kinase/mitogen-activated protein kinase (ERK/MAPK) through the MAPK and ERK kinase MEK. So what role do MEK and ERK/MAPK have in bFGF- or VEGFmediated apoptotic protection? The authors added the selective MEK inhibitor PD98059 to ECs that had been treated with either bFGF or VEGF and induced to undergo stressor receptor-mediated apoptosis, respectively. PD98059 affected only the VEGF-mediated protection of ECs, so bFGF-induced Raf-mediated protection from apoptosis seems to occur independently of MEK and ERK/MAPK.

Targeting c-Raf to the mitochondrial membrane is known to protect cells from stress-induced apoptosis, independently of MEK and ERK/MAPK. This led the authors to see if bFGF promoted Raf translocation to the mitochondria. After treatment with bFGF or VEGF, EClysates were fractionated, and the enriched cytoplasmic or mitochondrial fractions immunoblotted for c-Raf. bFGF, but not VEGF, promoted c-Raf mitochondrial translocation. Mutating the serines in the PAK phosphorylation site of $\mathrm{c}$-Raf blocked this translocation and the bFGF-mediated survival of ECs in response to stress. Similarly, mutating the tyrosines in the Src phosphorylation site of c-Raf prevented the VEGF-mediated protection from extrinsic apoptosis.

So, as indicated here, if different pro-survival factors can cooperate to alter the threshold of EC susceptibility to apoptotic factors, this might be something to bear in mind when designing drugs against tumour-

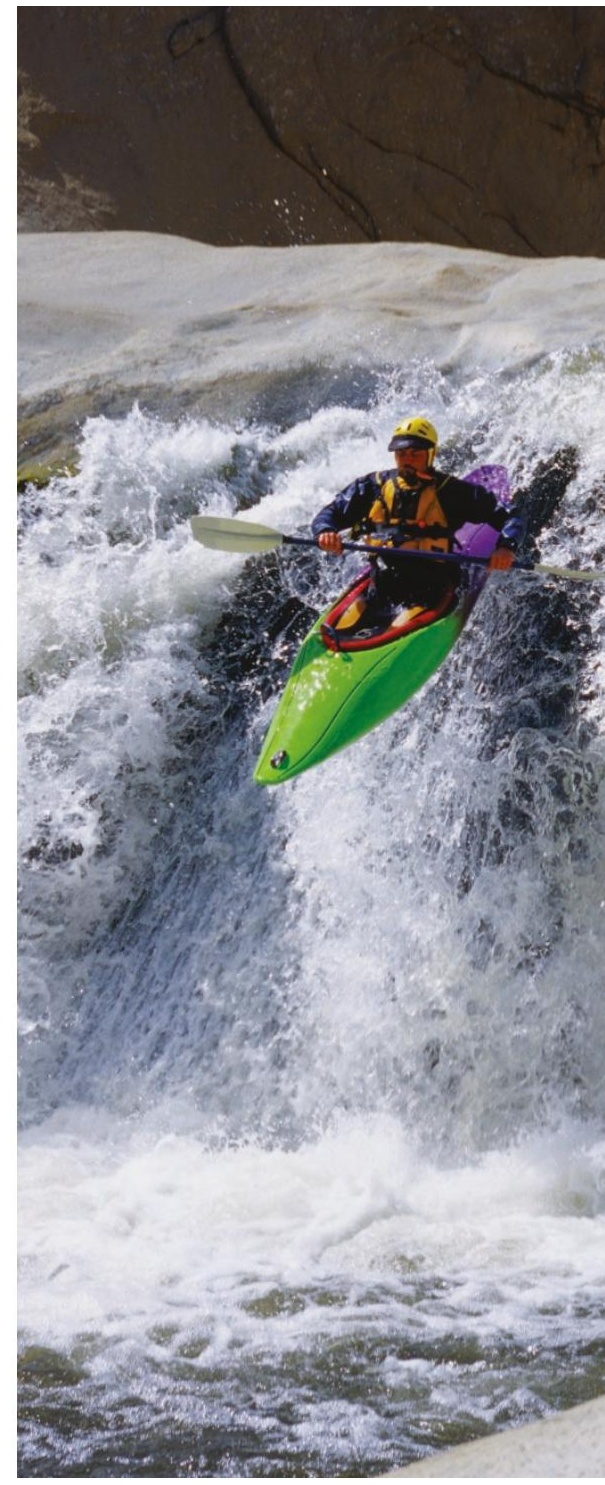

associated vasculature - combination therapies targeting these proapoptotic pathways might be more effective.

Katrin Bussell

(2) References and links ORIGINAL RESEARCH PAPER Alavi, A. et al. Role of Raf in vascular protection from distinct apoptotic stimuli. Science 301, 94-96 (2003) 